\title{
Gains from trans-boundary water quality management in linked catchment and coastal socio- ecological systems: a case study for the Minho region
}

\author{
Roebeling, Peter ${ }^{(a, 1)} \cdot$ Henrique Alves $^{(a)} \cdot$ João Rocha $^{(a)} \cdot$ António Guerreiro-Brito $^{(b)} \cdot$ Pedro Almeida $^{(a)} \cdot$ João Mamede ${ }^{(c)}$ \\ ${ }^{(1)}$ peter.roebeling@ua.pt • ${ }^{(a)}$ Dept. Environment and Planning \& CESAM, University of Aveiro • ${ }^{(b)}$ Dept. Biological Engineering - University of \\ Minho • (c)ARH-Norte - Dep. of Planning, Information \& Communication
}

Sustainable economic development requires balancing of marginal costs from catchment water pollution abatement and associated marginal benefits from freshwater/coastal ecosystem appreciation. Hence we need to differentiate between intra- and trans-boundary catchments because benefactors and beneficiaries from water quality improvement are not one and the same. In trans-boundary catchments, private (national) welfare maximizing rates of water quality improvement differ across nations as benefits from water quality improvement generally accrue to one nation while the costs are paid by multiple nations. In this paper we develop a deterministic optimal control approach to explore private and social welfare maximizing rates of water pollution abatement in linked catchment and freshwater/coastal socioecological systems. For a case study of the Minho region (Iberian Peninsula), we estimate nation-specific water pollution abatement cost functions (based on management practice adoption) to determine and compare private (national) and social (trans-national) welfare maximizing rates of water pollution abatement. Results show that some private (national) welfare gains can be obtained through adoption of win-win practices, leading to a $12 \%$ reduction in the annual rate of water pollution and a $7 \%$ increase in annual regional income. Maximum social (international) welfare gains can, however, be obtained through adoption of win-win and lose-win practices across Spain and Portugal, leading to a 36\% reduction in water pollution and a $14 \%$ increase in regional income. Non-cooperation in water pollution abatement would only lead to a 16\%-32\% reduction in water pollution and a 8\%-13\% increase in regional income. Hence, social (trans-national) welfare losses from non-cooperation between Spain and Portugal would equate to between 16 and $81 \mathrm{~m} € / \mathrm{yr}$. 


\section{TWAM 2013}

\section{International Conference \& Workshops}

Transboundary water management across borders and interfaces

present and future challenges
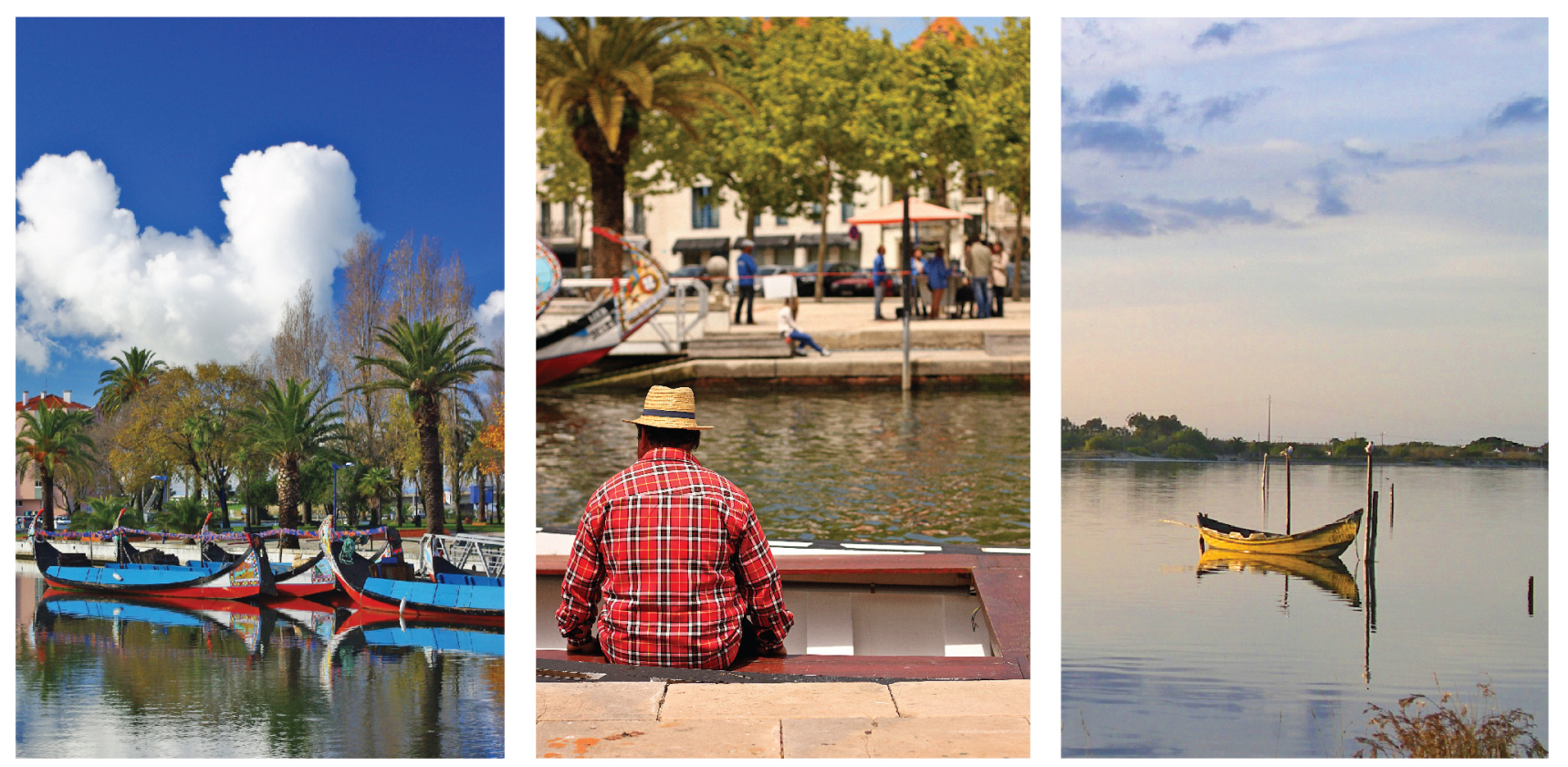

16 - 20th March 2013

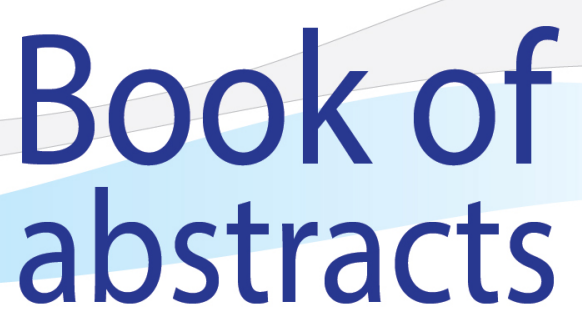

Aveiro - Portugal 
Book of abstracts

TWAM2013 International Conference \& Workshops

University of Aveiro, 16-20 March 2013, Aveiro, Portugal

Edited by:

Peter Roebeling and João Rocha

Roebeling, P.C. \& Rocha, J. (Eds), 2013. TWAM2013 International Conference \& Workshops - Book of abstracts. CESAM - Department of Environment \& Planning, University of Aveiro, Portugal. 93pp.

Aveiro, March 2013

ISBN: 978-972-789-377-5

Legal deposit: $356107 / 13$

Editors contact information:

- Peter Cornelis Roebeling

Centre for Environmental and Marine Studies (CESAM), Department of Environment and Planning (DAO),

University of Aveiro, Portugal.

E-mail: peter.roebeling@ua.pt.

- João Nuno Correia Rocha

Centre for Environmental and Marine Studies (CESAM), Department of Environment and Planning (DAO), University of Aveiro, Portugal.

E-mail: joaocrocha@ua.pt.

Artwork and book design by:

João Rocha

Acknowledgements:

This conference has been developed within the context of the Iberian Trans-boundary Water Management (IB-TWM) project, funded by the Fundação para a Ciência e a Tecnologia (FCT; PTDC/AAC-AMB/104301/2008) and the Fundo Europeu de Desenvolvimento Regional (FEDER; FCOMP-01-0124-011867-FEDER). Also, we would like to thank Carla Teotónio, Henrique Alves and Pedro Almeida for their critical remarks and helpful comments on earlier versions of this document.

${ }^{\odot}$ All rights reserved:

No part of this work may be reproduced, in any way or form, without prior written permission of the Editors and/or acknowledgement to the source.

Notes:

-Abstracts have been directly transferred from the contributor's submission and, hence, have not been checked or corrected for any spelling, grammatical and typographical errors.

-Please note that this Book of Abstracts includes all abstracts that were accepted for TWAM2013 International Conference \& Workshops. Not all abstracts will be presented at the conference. 